\title{
Britain puts industrialists into the driving seats of science policy
}

London. The British government has taken an important step towards its goal of putting the 'user community' in charge of the future direction of British science by appointing top industrial figures as the part-time nonexecutive chairmen of the two new research councils being set up following the publication of its white paper (policy document) on science and technology in May.

It has also appointed Sir John Cadogan, the former director of research at Britain's largest petrochemicals company, British Petroleum (BP), to the new post of director-general of research councils. This is a fulltime position within the Office of Science and Technology reporting directly to William Waldegrave, the cabinet minister responsible for science, who announced the appointments last week.

Alan Rudge, managing director of development and procurement at British Telecom (BT), is to be the chairman of the Engineering and Physical Sciences Research Council, the body which is to take over the more technology-orientated research fields of the Science and Engineering Research Council (SERC) when the latter is abolished in its current form next year.

At the same time, Peter Williams, chairman of Oxford Instruments Group plc, will become the chairman of the Particle Physics and Astronomy Research Council (PPARC). This is the body scheduled to take on the SERC's responsibilities in these two fields.

Still to be announced are the full-time chief executives of the two councils. At present, the functions of chairman and chief executive officer are combined at the SERC in a single position; the new arrangements have been introduced as part of the white paper's strategy for linking the science base more closely to the goal of wealth creation.

Wary of concern among scientists about industrialists being given responsibility for a significant part of the science base, both Rudge and Williams emphasize that they are committed to the value of long-term research. Each points out that his company relies heavily on close links with university researchers.

But both are also keen that the value of such research should be increasingly viewed from the point of view of the potential consumer - an approach which Rudge, for example, used as the central theme in his restructuring of BT's research strategy in the late $1980 \mathrm{~s}$.

Similar views are also expressed by Sir
John Cadogan, the new director-general of research councils. Currently visiting professor of chemistry at Imperial College, London, he spent 13 years directing the research activities of $\mathrm{BP}$, where he was responsible for the biggest industry-university collaborative research programme in the UK.

Cadogan was well known inside BP for his efforts to demonstrate the value of research to senior executives through the wide-

research at an early stage in its development, and of making scientists aware that, without wealth creation, there would be no funds for their work.

Williams, a solid-state physicist, also spent a period in academic life - as a lecturer at Imperial College, London before joining Oxford Instruments, one of Britain's most successful instrument manufacturers specializing in particular in superconducting technologies, in 1982. He became chief executive in 1985, and chairman in 1992.

$\mathrm{He}$, too, argues that wealth creation is a prerequisite for a healthy science base. But whereas BT, in its submission to the government during consultation on the white paper, explicitly argued that "resources should continue to be directed away from 'big science' towards technologies

spread use of cost-benefit analysis by its operating divisions. In particular he persuaded them to identify the precise contribution that company scientists had made to their divisional profits.

He claims that this approach succeeded in convincing management of the importance of the scientists' work. At the same time, it made the scientists aware that their activities were likely to be judged by their value as assessed by the operating divisions. "The failure of previous attempts at such cost benefit analysis was that it was always done by the researchers," he says.

Cadogan says he is aware that this approach may not be appropriate for all areas of government-funded research. But it does have a value, he says "when you have a bottom line". And he adds: "There is no reason why you should not look at it."

Rudge is an electrical engineer by training who, after a spell teaching at the University of Birmingham and in the United States, joined the telecommunications industry in 1979 as managing director of ERA Technology Ltd, joining BT as its director of research and technology in 1987.

At BT, already in the full throes of privatization, Rudge was associated with a wide-ranging restructuring of its research activities. This involved in particular bringing its laboratory scientists — including those supported on contracts in universities - directly in contact with product managers, often for the first time.

Rudge says that this experience taught him the importance of encouraging links between the producers and the users of associated with generating products and services", Williams (whose company had been hoping to provide superconducting wires for the Superconducting Super Collider before its cancellation) accepts that synergy can occur between certain branches of big science and physics-based industries, such as his own.

All three individuals have high reputations in the scientific community, and their appointments have been generally welcomed, although nervousness remains about the extent to which they will be able to persuade the government to take a longterm view of the country's future technological needs.

"We hope that one of John Cadogan's first actions will be to assure scientists that short-termism is not going to be a blight on the science base", says John Mulvey, secretary of the campaign Save British Science.

Mulvey also expresses concern at the delay in appointing the full-time executives of the two new research councils, which are now unlikely to be announced before Christmas. "We hope that the delay does not indicate difficulty in finding suitably qualified people prepared to take up these appointments", he says.

According to Sir Mark Richmond, the departing chairman of the SERC, the delay in making the new appointments is already imposing a "planning blight" on the two councils, at a time when the other research councils, such as the new Biotechnology and Biological Sciences Research Council, are already forging ahead with their future plans.
David Dickson 